\title{
PEMBUATAN ALAT BANTU KOMUNIKASI EDUKATIF UNTUK PENYANDANG CEREBRAL PALSY PANTI ASUHAN SAYAP IBU, BINTARO PROTOTYPE: FITTED HEAD POINTING DEVICE
}

\author{
Maitri Widya Mutiara' ${ }^{1}$, Augustina Ika Widyani², dan Margaretha Sandi ${ }^{3}$ \\ ${ }^{1}$ Program Studi Desain Interior, Universitas Tarumanagara, Jakarta \\ Email: maitrim@fsrd.untar.ac.id \\ ${ }^{2}$ Program Studi Desain Interior, Universitas Tarumanagara, Jakarta \\ Email: augustinaw@fsrd.untar.ac.id \\ ${ }^{3}$ Jurusan Arsitektur dan Perencanaan, Universitas Tarumanagara, Jakarta \\ Email: margarethas@ft.untar.ac.id
}

\begin{abstract}
Communication is the main tool for humans to convey information, especially for people with disabilities, communication is very much needed so that they can comunicate Communication will support educational patterns and people with disabilities will be able to get the ideal education. The Banten branch of the Sayap Ibu Foundation has a Special School which is an institution that is engaged in providing education for neglected children with special needs, especially persons with disabilities with Cerebral Palsy conditions. The contribution of product design procurement in designing user-based tools in providing educational communication aids for Cerebral Palsy children at the Sayap Ibu Orphanage is an effort to realize the design of assistive devices for independent educational patterns so that they can type with motor limitations in moving their fingers. Trials and fundamental research in multidisciplinary child development and special education combined in the contribution of tactical design, this design product was developed by the principal, therapist, and the writing team to be realized into a useful design product for Cerebral Palsy children in supporting communication in education they received. With the trial \& error method that has been carried out by partners, it is developed with detailed mapping of respondent activities that will be made on a 1: 1 scale for educational communication tools, namely Prototype: Fitted Head Pointing Device. The typing aid that is placed on the head and hands due to the limitations of the respondents in moving their fingers is considered very effective in helping them to type and express their limited forms of communication.
\end{abstract}

Keywords: cerebral palsy, educational communication, design of assistive devices, design product

\begin{abstract}
ABSTRAK
Komunikasi adalah alat dan modal utama untuk manusia dapat menyampaikan informasi, terutama untuk penyandang disabilias komunikasi menjadi sangat dibutuhkan untuk mereka dapat menyampaikan informasi dan mendapatkan informasi. Komunikasi akan menunjang pola edukasi dan penyandang disabilitas akan dapat mendapatkan pendidikan yang ideal. Yayasan Sayap Ibu cabang Banten memiliki Sekolah Sayap Ibu yang merupakan salah satu lembaga yang bergerak di bidang penyelenggaraan pendidikan bagi anak-anak berkebutuhan khusus yang terlantar khususnya penyandang disabilitas dengan kondisi Cerebral Palsy. Kontribusi pengadaan produk desain dalam perancangan alat bantu berbasis pengguna dalam penyediaan alat bantu komunikasi edukatif untuk anak Cerebral Palsy Panti Asuhan Sayap Ibu ini adalah upaya mewujudkan perancangan alat bantu untuk pola edukasi mandiri agar mereka dapat mengetik dengan keterbatasan motorik dalam menggerakan jemari tangan mereka. Uji coba riset mendasar dalam multidisiplin tumbuh kembang anak dan pendidikan khusus dipadu dalam kontribusi desain taktis produk desain ini dikembangkan oleh kepala sekolah, terapis, dan tim penulis untuk dapat di realisasikan menjadi sebuah produk desain yang bermanfaat untuk anak Cerebral Palsy dalam menunjang komunikasi di pendidikan yang mereka terima. Dengan metode uji coba (trial \& eror) yang telah di lakukan pihak mitra di kembangkan dengan pemetaan detail aktivitas responden akan dibuat dalam skala 1:1 alat bantu komunikasi edukatif yaitu Prototype: Fitted Head Pointing Device. Alat bantu mengetik yang di letakan di kepala dan tangan karena keterbatasan responden dalam menggerakan jemari ini dianggap sangat efektif untuk membantu mereka dapat mengetik dan mengekspresikan bentuk komunikasi mereka yang terbatas.
\end{abstract}

Kata Kunci:cerebral palsy, komunikasi edukatif, perancangan alat bantu, produk desain. 


\section{PENDAHULUAN}

Yayasan Sayap Ibu (YSI) disertai Sekolah Sayap Ibu cabang Banten merupakan sebuah tempat penampungan bernaung berkebutuhan khusus yang berada di Wilayah Provinsi Banten dengan 80\% penyandang Cerebral Palsy. Lokasi Yayasan Sayap Ibu adalah di Jalan Raya Graha Bintaro No. 33 B RT 004/RW 01 Pondok Kacang Barat, Bintaro,Tangerang Selatan. YSI sangat terbuka dan sering menjalin kerjasama dengan pihak UNTAR dalam berbagai aspek dan konteks bidang keilmuan. Dengan fokus kepada kualitas hidup siswa nya Sekolah Sayap Ibu berinisiatif aktif dalam mengembangan fasilitas dan sarana belajar penunjang untuk siswa dengan berbagai keterbatasan kemampuan. Program PKM ini berupaya menjadi bentuk sumbangsih dan kontribusi nyata UNTAR untuk mewujudkan pendidikan berkualitas untuk siswa penyandang Cerebral Palsy terutama dalam konteks besar bidang sosial edukasi bagi anak cacat terlantar, mengingat kurangnya wujud nyata dari subtansi pendidikan bagi masyarakat golongan terlantar dan juga disabilitas di Indonesia.

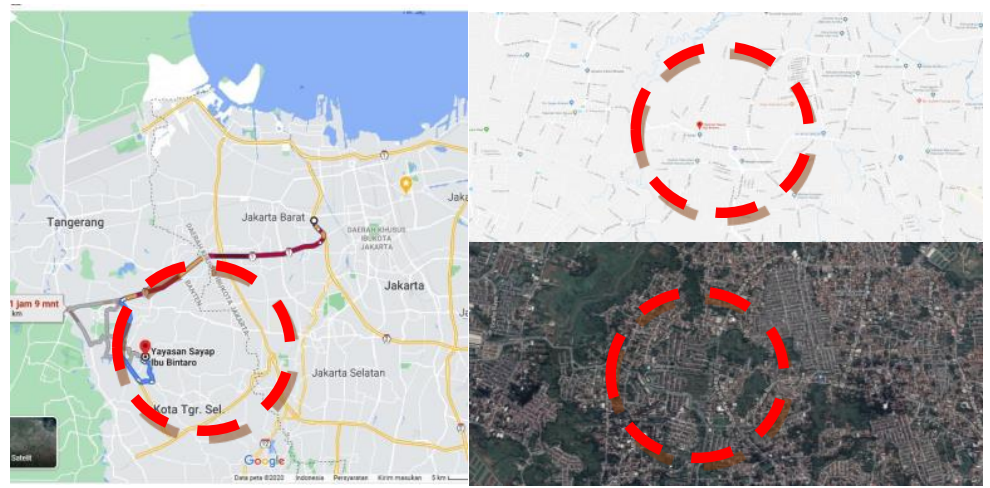

Gambar 1. Lokasi Yayasan Sayap Ibu Bintaro yang Berjarak Sekitar 20K dari Universitas Tarumanagara

(Sumber: disunting dan dilengkapi dari https://www.google.co.id/maps)

\section{Analisis situasi}

Yayasan Sayap Ibu cabang Banten secara berkala menerima siswa baru tanpa kehilangan siswa lama, 90\% kegiatan edukasi baik kepada masyarakat umum hingga keluarga yang memiliki anggota keluarga dengan kondisi khusus di edukasi di YSI di bawah naungan Sekolah Khususnya dan beberapa anak Panti Asuhannya yang dapat mengemban ilmu diberikan fasilitas terprogram untuk mereka juga dapat menerima pendidikan artinya jumlah penghuni pada tempat penampungan siswa berkebutuhan khusus terlantar selalu bertambah jumlahnya dan bahkan sering dijadikan acuan oleh masyarakat umum. Upaya aktif dari pihak YSI ini mengalami banyak sorotan karena siswa yang dididik dapat membaca, menulis, bahkan hingga berusaha untuk dapat berpenghasilan mandiri. Pendidikan adalah salah satu cara utama untuk memberikan kualitas hidup yang lebih baik kepada penyandang disabilitas untuk dapat berkarya dan bertahan hidup. Dengan diajukannya proposal kepada salah satu tim penulis, dan melihat situasi pendidikan di Sekolah Khusus YSI diharapkan kegiatan PKM ini mengambil peran penting dalam mewujudkan mimpi para penyandang disabilitas khususnya Cerebral Palsy.

\section{Permasalahan mitra}

Dengan adanya 26 penyandang Cerebral Palsy di YSI dan 60\% di dalamnya memiliki kemampuan pemahaman serta dapat mengikuti kegiatan pembelajaran dengan cukup baik YSI memfokuskan untuk dapat memaksimalkan edukasi kepada penyandang Cerebral Palsy (CP) mampu didik ini. Mengingat bahwa kondisi $\mathrm{CP}$ adalah gangguan motorik dengan berbagai keterbatasan fungsi gerak, mitra sangat memerlukan adanya alat bantu aktivitas/ assistive tools 
pada beberapa penyandang untuk memaksimalkan proses belajar megajar. Jelas permasalahan mitra karena YSI adalah lembaga non profit yang bergantung pendanaannya pada donatur, fasilitas dan sarana alat bantu sulit untuk di realisasikan. Sehingga dapat disimpulkan permasalahan mitra adalah sbb: (1). Kesulitan berkomunikasi dengan penyandang CP mampu didik.; (2). Kurang optimalnya kegiatan edukasi untuk siswa penyandang CP; (3). Tidak adanya ketersediaan alat bantu komunikasi yang edukatif. Sehingga dapat disimpulkan permasalahan mitra dapat diberikan solusinya dalam kegiatan PKM ini.

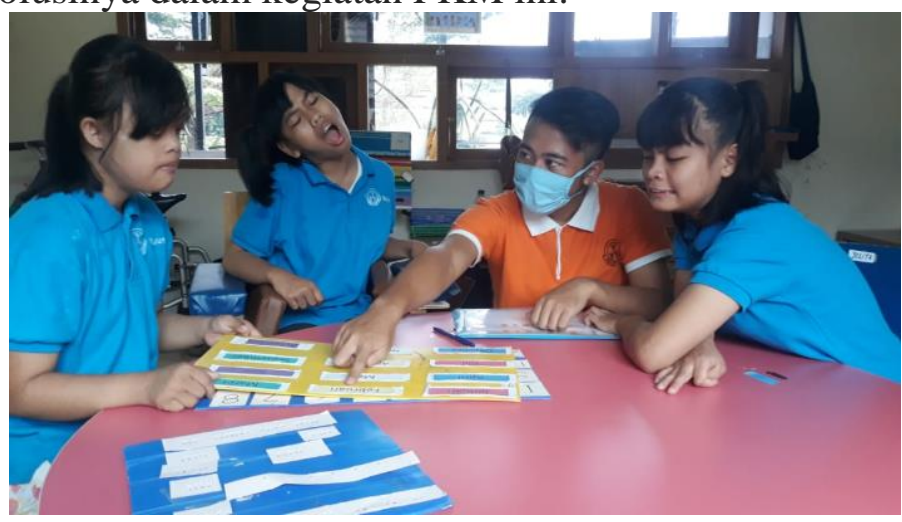

Gambar 2. Kegiatan Belajar Mengajar di Sekolah YSI

(Sumber: Dokumentasi Pribadi, 2020)

\section{METODE PELAKSANAAN PKM}

Metode pelaksanaan dalam pembuatan alat komunikasi edukatif untuk penyandang Cerebral Palsy dari Yayasan Sayap Ibu cabang Banten dengan 3 responden yakni; Ubay, Ucup, dan Bella (masing-masing mewakili Level I,II, \& III kondisi CP) menggunakan Grounded Research Methods mengacu kepada kualitatif analisis data. Tahapan program Pengabdian Kepada Masyarakat di Yayasan Sayap Ibu cabang Banten akan dibagi menjadi 3 (tiga) tahapan, yaitu : (1). Tahap Pendataan \& Mapping Prilaku Responden; (2). Tahap Perencanaan, Percobaan \& Pembuatan Mock-Up Skala 1:1; (3). Tahap Pelaksanaan Akhir

Tahap Pendataan \& Mapping Prilaku Responden dibutuhkan untuk mendapatkan spesifikasi kebutuhan dan gambaran awal bentuk serta detail konsep desain yang diperlukan sesuai dengan kebutuhan serta kondisi keterbatasan pengguna, dibantu oleh Guru, Terapis, dan Pengasuh dari YSI. Karena responden tidak dapat diwawancarai langsung dibutuhkannya pengamatan dan diskusi terstruktur antara tim YSI diatas agar data yang dikumpulkan dan mapping prilaku belajar dan komunikasi yang di dapat validasinya jelas. Tahap pendataan serta pengamatan responden ini amat penting dilakukan agar pembuatan alat bantu sangat presisi atas setiap keterbatasan dalam kondisi pengguna.

Tahap Perencanaan, Percobaan \& Pembuatan Mock-Up Skala 1:1 meliputi perencanaan awal yang didukung oleh data yang telah dikumpulkan serta Grounded Research test (trial \& error) (Galal,1997) dalam menguji ulang konsep awal dari pengolahan data sehingga di perlukannya percobaan dan pembuatan sample alat bantu untuk mengukur seberapa tepat alat yang didesain awal dapat berfungsi (Hughes, 2000). Lalu dilanjutkan ke Tahap pelaksanaan Akhir dimana monitoring dan evaluasi dilakukan bersama oleh tim mitra untuk menyimpulkan konsep desain perencanaan akhir yang di revisi dan di realisasikan untuk di gunakan mitra dalam proses edukasi. Partisipasi mitra dalam kegiatan PKM dalam hal ini diwakili oleh beberapa terapis tumbuh kembang anak beberapa orang guru yang mengajar di beberapa kelas, serta kepala sekolah 
sekaligus pengelola Yayasan Sayap Ibu cabang Banten. Mitra ikut berpartisipasi dalam hal sebagai berikut: pengumpulan data, menjelaskan pengetahuan terkait aktifitas anak CP, membantu pelaksanaan uji coba penggunaan alat peraga, memberikan laporan evaluasi, membuat alat peraga dengan kerjasama dengan tenaga pengrajin lokal.

Tim pengusul merupakan dosen-dosen yang pernah terlibat pada mata kuliah desain furniture, ergonometri/ faktor prilaku manusia dalam Program Studi Desain Interior serta Kajian Psikologi Arsitektur di Jurusan Arsitektur dan Perencanaan Universitas Tarumanagara. Dengan demikian, tim dosen memiliki latar belakang keilmuan yang dianggap mumpuni dalam membahas perilaku yang dikaitkan dengan konsep desain furniture \& produk arsitektur arsitektural. Dalam hal ini, implementasi yang dilakukan adalah:

\section{a. Tahap Pendataan \& Mapping Prilaku Responden}

Tiga orang dosen berperan dalam kegiatan survey langsung ke lapangan, berkolaborasi dengan therapis \& tenaga pendidik (Guru Sekolah Sayap Ibu) untuk mengumpulkan dan mengolah datadata yang diperlukan dari 2 Responden dengan diagnosa Cerebral Palsy, menggunakan pemahaman investigasi yang dikembangkan menjadi sebuah acuan kerja (Orlikowski, 1993). Kegiatan yang dilakukan adalah observasi dan pengamatan situasi secara langsung dilengkapi dengan kegiatan wawancara kepada pengelola dan narasumber terkait (pengguna /user dan tenaga pengajar serta karyawan di lingkungan Yayasan Sayap Ibu).

\section{b. Tahap Perencanaan, Percobaan \& Pembuatan Mock-Up Skala 1:1}

Dengan bekerjasama langsung dengan therapis \& guru di Sekolah Sayap Ibu kegiatan ini dilakukan oleh tiga orang dosen untuk proses desain, satu orang pengrajin besi \& 1 orang pengrajin kayu serta dukungan dari tenagara kerja Yayasan Sayap Ibu Bintaro. Pada tahapan ini, kegiatan berupa pengolahan data hasil survey dan pembuatan konsep desain hingga tahap pembuatan sample untuk di uji coba. Pada tahap ini pula tim PKM melibatkan mitra dan user untuk memberikan komentar/ masukan terhadap desain untuk dapat di evaluasi kembali mencapai desain akhir.

\section{c. Tahap Pelaksanaan Akhir}

Kegiatan ini dilakukan oleh satu orang dosen dibantu oleh satu orang mahasiswa untuk proses penggambaran gambar kerja, serta dengan tim tenaga pengrajin alat dari yayasan Sayap Ibu untuk merevisi serta mewujudkan prototipe Fitted Head Pointing Device yang di perlukan. Pada tahapan ini, kegiatan berupa penggambaran detail desain alat bantu aktivitas yang meliputi gambar dua dimensi dengan menggunakan program Autocad dan penggambaran wujud tiga dimensi dengan menggunakan program Sketchup \& Adobe Photoshop hingga kegiatan ketukangan yang dilaksanakan akan dilaksanakan secara sistematis dan kolaboratif. Pada tahap ini diproduksi sebuah dokumen gambar perancangan yang memuat detail dimensi dan material dari desain alat \& skala 1:1 prototipe Fitted Head Pointing Device untuk di gunakan oleh pihak Yayasan Sayap Ibu. Laporan keuangan dicatatkan oleh ketua pengusul, sedangkan laporan akhir nantinya akan dikerjakan secara bersama-sama.

\section{HASIL DAN PEMBAHASAN}

\section{Pentingnya Pendidikan Untuk Penyandang Cerebral Palsy}

Pendidikan menjadi salah satu fondasi utama manusia untuk tetap dapat menjalani hidup dengan masa depan yang lebih cerah dan kualitas hidup yang lebih baik, tidak terkecuali bagi siswa penyandang Cerebral Palsy (Adelman,1983). Cerebral Palsy merupakan suatu cacat yang 
disebabkan oleh adanya gangguan yang terdapat dalam otak/ sering dikenal dengan istilah lumpuh otak, cacatnya bersifat kekakuan pada anggota geraknya, kelayuhan, gangguan koordinasi, getaran-getaran ritmis dan gangguan sensoris. Cerebral Palsy ditandai oleh adanya kelainan gerak, sikap atau bentuk tubuh, gangguan koordinasi, kadang-kadang disertai gangguan psikologis dan sensoris yang disebabkan oleh adanya kerusakan atau kecacatan pada masa perkembangan otak. Dalam mengembangkan pendidikan sebagai proses pemberdayaan anak didik, secara filsafat harus berpijak pada fakta dan realita. Proses pendidikan melalui pelaksanaan kegiatan pembelajaran harus memberikan kesempatan yang seluasnya bagi peserta didik untuk mengembangkan sense of interest, sense of curiosity, sense of reality, dan sense of discovery dalam mempelajari fakta untuk mencari kebenaran (Sumaatmadja, 2002). Pendidikan bagi anak berkebutuhan khusus adalah usaha untuk membantu dan membimbing anak didik untuk mencapai kedewasaan serta kemandirian melalui pembelajaran, baik formal maupun informal. Sehingga menjadi sangat penting untuk menyediakan kelayakan pendidikan untuk siswa penyandang $\mathrm{CP}$.

\section{Klasifikasi Cerebral Palsy}

Klasifikasi CP berdasarkan:

\section{(1) Tipe dan keparahan abnormalitas motorik/ Topografi;}

Monoplegia, hanya satu anggota gerak yang lumpuh misal kaki kiri sedang kaki kanan dan kedua tangannya normal. Hemiplegia, lumpuh anggota gerak atas dan bawah pada sisi yang sama, misalnya tagan kanan dan kaki kanan, atau tangan kiri dan kaki kiri. Paraplegia, lumpuh pada kedua tungkai kakinya. Diplegia, lumpuh kedua tangan kanan dan kiri atau kedua kaki kanan kiri. Triplegia, tiga anggota gerak mengalami kelumpuhan, misalnya tangan kanan dan kedua kakinya lumpuh, atau tangan kiri dan kedua kakinya lumpuh. Quadriplegia, anak jenis ini mengalami kelumpuhan seluruhnya anggota geraknya. Mereka cacat pada kedua tangan dan kedua kakinya, quadriplegia disebut juga tetraplegia. Berdasarkan keparahan abnormalitas $\mathrm{CP}$ tergantung dari fungsi mana dan berapa bagian yang terbatas dalam digerakan (Shamsoddini,2014).

\section{(2) Distribusi anatomi ekstremitas / Menurut Fisiologi Kelainan Gerak;}

Spastik: ditandai dengan adanya gejala kekejangan atau kekakuan pada sebagian atau pun seluruh otot. Kekakuan itu timbul sewaktu akan digerakkan sesuai dengan kehendak. Dalam keadaan ketergantungan emosional kekakuan atau kekejangan itu akan makin bertambah, sebaliknya dalam keadaan tenang, gejala itu menjadi berkurang. Pada umumnya, anak Cerebral Palsy jenis spastik ini memiliki tingkat kecerdasan yang tidak terlalu rendah. Di antara mereka ada yang normal bahkan ada yang di atas normal. Athetoid: Pada tipe ini, penyandang tidak terdapat kekejangan atau kekakuan. Otot-ototnya dapat digerakkan dengan mudah. Ciri khas tipe ini terdapat pada sistem gerakan. Hampir semua gerakan terjadi di luar kontrol. Gerakan yang dimaksud adalah dengan tidak adanya kontrol dan koordinasi gerak. Ataxia: Adapun ciri khas tipe ini adalah seakan-akan kehilangan keseimbangan, kekakuan memang tidak tampak tetapi mengalami kekakuan pada waktu berdiri atau berjalan. Gangguan utama pada tipe ini terletak pada sistem koordinasi dan pusat keseimbangan pada otak. Akibatnya tipe ini mengalami gangguan dalam hal koordinasi ruang dan ukuran, sebagai contoh dalam kehidupan sehari-hari yaitu pada saat makan mulut terkatup terlebih dahulu sebelum sendok berisi makanan sampai ujung mulut. Tremor: Gejala yang tampak jelas pada tipe tremor adalah senantiasa dijumpai adanya gerakan-gerakan kecil dan terus menerus berlangsung sehingga tampak seperti bentuk getaran-getaran. Gerakan itu dapat terjadi pada kepala, mata, tangkai, dan bibir. Rigid: Pada tipe ini penyandang tunadaksa mendapati gejala kekakuan otot, akan tetapi tidak seperti pada tipe spastik, gerakannya tampak tidak ada keluwesan, gerakan mekanik lebih tampak dan nyata. Dan yang terakhir adalah Tipe 
Campuran: Pada tipe ini seorang penyandang tunadaksa akan menunjukkan dua jenis atau pun lebih gejala gabungan diatas, sehingga akibatnya lebih berat bila dibandingkan dengan anak yang hanya memiliki satu jenis/tipe kecacatan (Novak , 2017).

Inti dari klasifikasi diatas adalah Cerebral Palsy merupakan salah satu bentuk brain injury, kondisi tersebut mempengaruhi pengendalian sistem motorik sebagai lesi dalam otak atau suatu penyakit neuromuscular yang disebabkan oleh gangguan perkembangan atau kerusakan sebagian dari otak yang berhubungan dengan pengendalian fungsi motorik (Somantri, 2005). Mengapa detail klasifikasi menjadi penting dalam penelitian ini, karena dengan latarbelakang diagnosa yang berbeda juga dapat memiliki spesifikasi desain yang berbeda juga. Untuk kebutuhan berdasarkan tipe gross motor function, dalam penelitian ini prototipe akan di bagi menjadi (Palisano, 1997);

1. Level I (Tipe Klasifikasi Rendah) : Acuan diagnosa responden tidak berat sehingga spesifikasi detail yang dibutuhkan pada alat bantu tidak banyak.

2. Level II (Tipe Klasifikasi Sedang) : Acuan sedang biasanya ada gabungan 1-3 kelainan motorik dan memiliki kebutuhan spesifikasi sedang pada alat bantu.

3. Level III (Tipe Klasifikasi Tinggi) : Acuan tinggi mengarah kepada responden dengan kondisi keterbatasan gabugan lebih dari 3 jenis hingga membutuhkan spesifikasi detail pada alat bantu cukup banyak.

\section{Hasil Diskusi Dengan Mitra Berdasarkan Referensi Literatur}

Tabel 1. Diskusi Referensi Bersama Mitra

\begin{tabular}{ll}
\hline No & \multicolumn{1}{c}{$\begin{array}{c}\text { Hasil Diskusi Tim } \\
\text { (Terapis, Guru \& Pengasuh Pengguna) }\end{array}$} \\
\hline 1 & $\begin{array}{l}\text { Karena kondisi pengguna dilihat pada gambar referensi ini } \\
\text { tidak menyandang Cerebral Palsy (CP) mitra PKM } \\
\text { beranggapan dasar bahwa kemungkinan harus ada korelasi } \\
\text { antara mata dan sudut pandang yang derajatnya akan } \\
\text { sangat berbeda dengan gambar referensi ini. }\end{array}$ \\
\hline 3 & $\begin{array}{l}\text { Serupa dengan kondisi pengguna di YSI, dengan } \\
\text { kondisi CP Spastik Hemiplegia, ketika } \\
\text { mengamati gambar ini terlihat bahwa sudut juga } \\
\text { dipengaruhi dengan peletakan orientasi meja dan } \\
\text { kursi roda. }\end{array}$ \\
\hline $\begin{array}{l}\text { Sama dengan kondisi no 2 diatas, namun } \\
\text { orientasi meja berbeda dapat menghasilkan hasil } \\
\text { yang berbeda dari sudut pandang dan konsentrasi } \\
\text { pada responden yang tidak mampu mengangkat } \\
\text { kepalanya. }\end{array}$ &
\end{tabular}




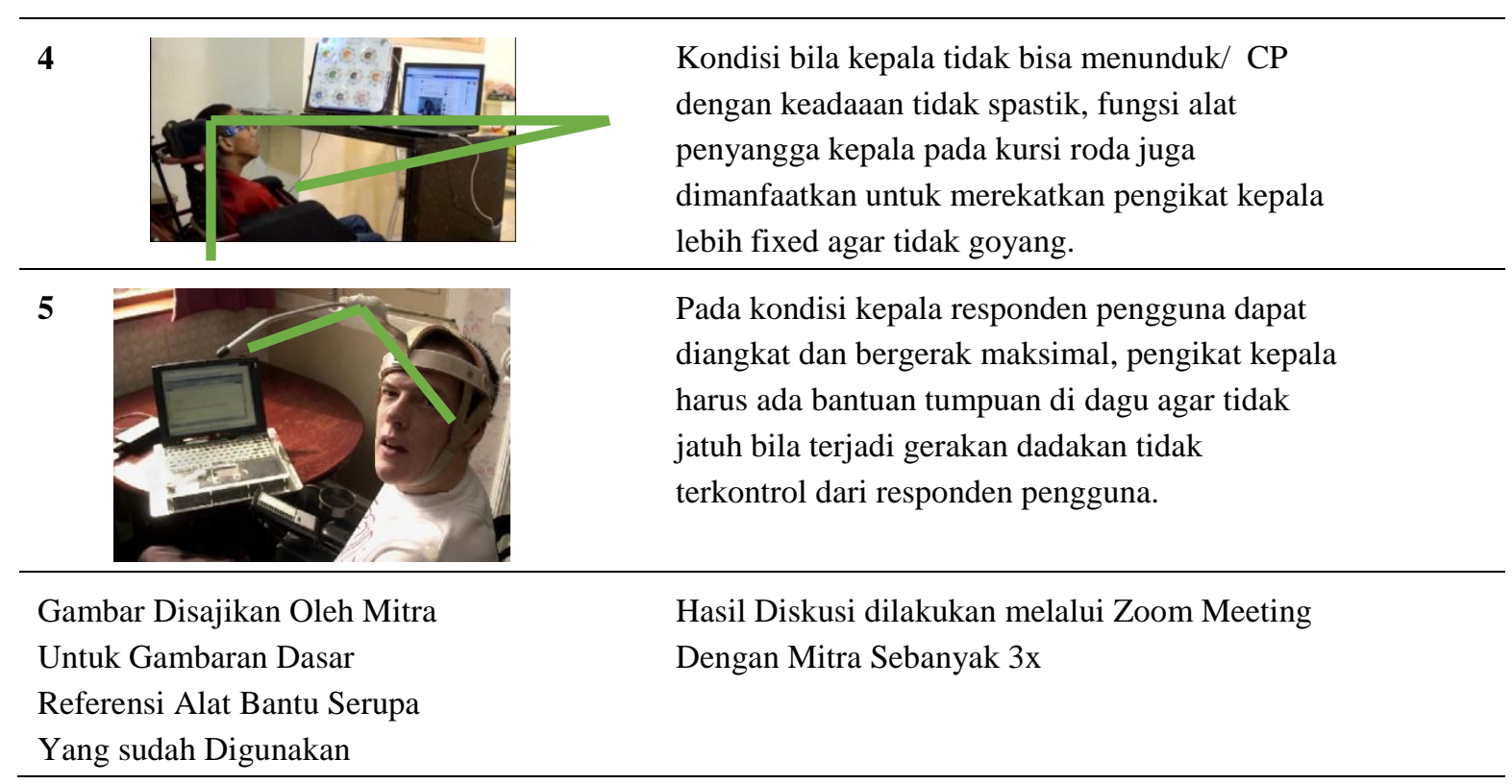

\section{Sumber: Gambar Referensi Dari Mitra, Diedit Oleh Penulis, 2020}

Berdasarkan Diskusi diatas dan disetujuinya pendanaan PKM dari LPPM dengan pendanaan awal dari mitra, dilakukannya uji coba pertama berdasarkan diskusi diatas untuk mendapatkan detail penggambaran spesifik berdasarkan kebutuhan pengguna sbb;

Tabel 2. Proses Pembuatan Sample \& Uji Coba

\begin{tabular}{llll}
\hline No Proses Uji Coba & Laporan Kegiatan \\
\hline $\begin{array}{l}\text { Proses Pembuatan } \\
\text { Pointer }\end{array}$ & $\begin{array}{l}\text { Dengan pertimbangan fasilitas belajar dan } \\
\text { keterbatasan fungsi pengguna, di coba untuk } \\
\text { sudut pointer dengan penyesuaian keyboard, } \\
\text { meja belajar, dan kursi roda yang digunakan } \\
\text { pengguna dilihat kurang presisi. }\end{array}$ \\
\hline 2 Proses Pembuatan \\
$\begin{array}{l}\text { Pengikat Kepala } \\
\text { Proses Uji Coba }\end{array}$
\end{tabular}




4 Proses Pengajaran $\quad \begin{aligned} & \text { Adanya sudut pointer dan pengikat kepala } \\ & \text { yang kurang tepat sehingga pengguna perlu } \\ & \text { melakukan effort lebih dalam } \\ & \text { penggunaannya. }\end{aligned}$

Sumber: Penulis, 2020

Dalam diskusi referensi dan uji coba didapatkan bahwa untuk Level I,II, dan III didapati perbedaan detail pengikat kepada untuk alat bantu ini. Hasil dari diskusi dan uji coba menitik beratkan kepada aspek sbb: (1).Sudut Peletakan Pointer; (2). Konfigurasi peletakan meja dan kursi roda; (3). Material Pengikat Kepala; (4). Panjang Pointer; (5). Sambungan dari Pointer terhadap Pengikat Kepala.

\section{Fitted Head Pointing Device Sebagai Usulan Alat Bantu Komunikasi Edukatif}

\section{Identifikasi Keterbatasan Kemampuan \& Kebutuhan Pengguna}

Kondisi pengguna dengan keterbatasan motorik dalam menggunakan jemari dan kedua lengan serta usaha dari pihak mitra untuk meningkatkan kualitas kehidupan dan pendidikan pengguna dapat dinyatakan adanya kebutuhan dari Yayasan Sayap Ibu terhadap pengadaan peralatan penunjang, maka dibutuhkan sebuah kerjasama dengan pihak yang dapat menyediakan peralatan tersebut. Proposal pengadaan alat peraga penunjang yang tergolong assistive tools ini dapat digunakan untuk mendukung kualitas komunikasi dalam pendidikan pengguna. Usulan desain peralatan berupa alat bantu aktivitas edukasi; penting untuk disadari perlu didasari atas pengamatan perilaku dan berdasarkan kegiatan psikomotorik dengan spesifikasi tertentu. Hal tersebut dicapai melalui diskusi terkait kebutuhan pengguna, guru serta terapis berdasarkan perilaku dan keterbatasan pengguna. Bertepatan dengan latar belakang Tim Pengusul yang berhubungan dengan perancangan furniture, produk arsitektur, perilaku pengguna, dan juga detail ergonometri yang menjadi melengkapi kebutuhan mitra,

Disabilitas khususnya Penyandang Cerebral Palsy memang memiliki fungsi gerak yang sangat terbatas, namun beberapa dari mereka dapat secara maksimal menggunakan salah satu fungsi gerak tubuhnya, bagian yang disoroti pada konteks ini adalah pengguna mampu menggunakan kepala dengan sangat baik dalam berkomunikasi. Aktifitas yang dapat dilakukan kepala di dalam kelas adalah sebagai pengganti lengan dan bahkan jemari. Berdasarkan wawancara dengan guru atau terapis responden dapat secara baik menggunakan kepalanya. Sekolah Sayap Ibu; pada saat melakukan aktivitas misal komunikasi dengan pengguna dengan keterbatasan tersebut membutuhkan sebuah alat bantu (assistive tools). Terdapat beberapa kriteria yang disampaikan oleh mitra (Yayasan Sayap Ibu) dan pengguna (anak penderita CP) terkait alat bantu yang diharapkan, antara lain; mudah dibuat dan di perbaiki, pembuatan dengan biaya terjangkau (sehingga dapat dibuat banyak untuk beberapa pengguna), kokoh, dan sesuai spesifikasi kebutuhan setiap responden.

\section{Fitted Head Pointing Device Sebagai Wujud Alat Bantu Komunikasi Edukatif}

Dari hasil diskusi dan wawancara terhadap Yayasan Sayap Ibu yang terdiri dari Guru, Therapis, dan Pengurus anak panti yang sudah mengenal pola dan kebutuhan keseharian komunikasi pengguna, tim pengusul mendapatkan ide dasar dari pihak mitra dan di kembangkan untuk berupaya melakukan pencarian ide desain dengan mengaitkan referensi 
terkait kebutuhan, efektifitas pembuatan, serta ketepatan penggunaan dengan memperhatikan ergonometri serta mapping prilaku pengguna dalam data yang sudah di kumpulkan. Meninjau kembali kondisi pengguna dengan Cerebral Palsy Spastik Hemiplegia serta kondisi medis bawaan menurut catatan medis terakhir yang dimiliki mitra, adapun solusi yang ditawarkan kepada mitra adalah sebuah Fitted Head Pointing Device (alat bantu di kepala untuk mengarah ke keyboard komputer). Fitted Head Pointing Device adalah sebuah alat bantu untuk pengguna dapat mengetik di komputer, atau sesederhana dapat menulis di personal computer untuk dapat mengekspresikan bentuk komunikasi dengan baik dalam proses edukasi. Kondisi pengguna yang tidak dapat berbicara namun mengerti untuk ingin menyampaikan informasi dalam sebuah proses edukasi sangat terjawab dengan adanya alat bantu ini. Fitted Head Pointing Device diharapkan dapat menjadi solusi untuk pengajar pendidikan khusus di Sekolah Sayap Ibu untuk dapat berkomunikasi dan menjalani proses edukasi dengan lebih baik.

Tabel 3. Spesifikasi Fitted Head Pointing Device

\begin{tabular}{lllll}
\hline No & Spesifikasi & Ukuran & Material & Keterangan \\
\hline 1 & $\begin{array}{l}\text { Pengikat Kepala Bagian } \\
\text { Atas }\end{array}$ & d: $20-25 \mathrm{~cm}$ & $\begin{array}{l}\text { Fabric } \\
\text { (oscar + busa) }\end{array}$ & Fixed \\
\hline 2 & $\begin{array}{l}\text { Pengikat Kepala Bagian } \\
\text { Tengah (Kening) }\end{array}$ & d:20-30 cm & PVC + Busa & Adjustable \\
\hline 3 & $\begin{array}{l}\text { Pengikat Kepala Bagian } \\
\text { Bawah (Dagu) }\end{array}$ & o: $5-8 \mathrm{~cm}$ & $\begin{array}{l}\text { PVC + Busa + } \\
\text { Fabric }\end{array}$ & Adjustable \\
\hline 4 & $\begin{array}{l}\text { Sambungan Pengikat } \\
\text { Kepala \& Pointer }\end{array}$ & 1: $32.5-5 \mathrm{~cm}$ & Metal Dilapis Fabric & Fixed \\
\hline 5 & Penyangga Pointer & p: $15-25 \mathrm{~cm}$ & Metal & Moveable \\
\hline 6 & Pointer Bagian Pangkal & $\mathrm{d}: 1-2 \mathrm{~cm}$ & Metal + Rubber & Fixed \\
\hline 7 & Pointer Bagian Ujung & $\mathrm{d}: 1-2 \mathrm{~cm}$ & Metal + Rubber & Fixed \\
\hline 8 & Pengikat Kepala Bagian & p: $20-40 \mathrm{~cm}$ & $\begin{array}{l}\text { Fabric (Oscar+ } \\
\text { Busa) }\end{array}$ & Adjustable \\
\hline
\end{tabular}

Sumber: Penulis, 2020

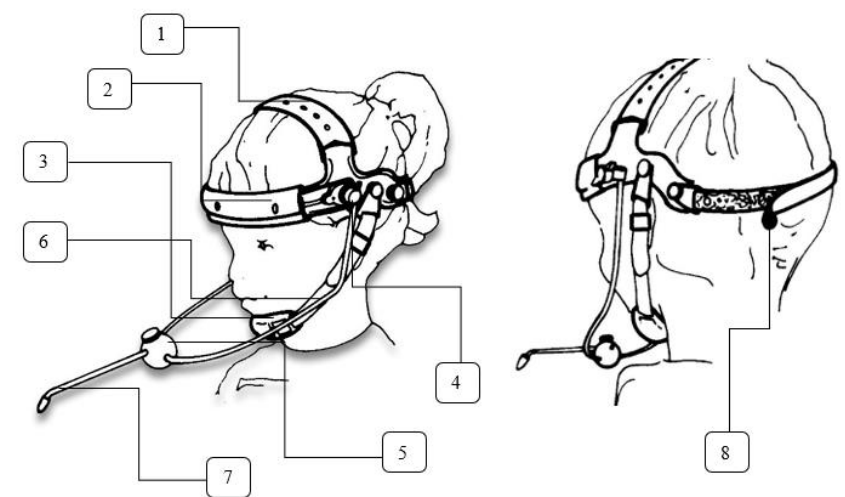

Gambar 3. Desain Fitted Head Pointing Device Sebagai Alat Bantu Komunikasi Edukatif

Sumber: Penulis, 2020. ref:specialneedscomputers.ca

\section{KESIMPULAN DAN SARAN}

Dalam pelaksanaan PKM ini ditemukan kendala yang berarti, baik dalam desain yang harus di diskusikan bersama terapis, guru, dan pengasuh dikarenakan pengguna tidak dapat 
berbicara; hingga proses spesifikasi data kadang ketika di uji coba kurang tepat. Kendala dan masalah yang diakibatkan dari Pembatasan Sosial Berskala Besar (PSBB) juga menjadi kendala yang cukup berarti, karena tim penulis tidak diijinkan mengamati langsung karena alasan protokol kesehatan sehingga segala pengamatan di lakukan dengan sistem daring. Pelaksanaan dilakukan sesuai dengan rencana awal dengan bantuan besar dan kerjasama cukup baik dengan mitra namun mengalami kemunduran dalam hal waktu dan cara pelaksanaan karena kesulitan mendapatkan pengrajin dan ujicoba yang sulit diamati melalui daring. Proses desain alat bantu komunikasi edukatif bagi penyandang Cerebral Palsy untuk Yayasan Sayap Ibu cabang Banten telah dilaksanakan dan cukup berhasil dalam tolak ukur fungsi, pelaksanaan hingga akhir November 2020 adalah sampai uji coba tahap pertama dan akan dilanjutkan hingga pelaksanaan akhir. Evaluasi dan revisi alat bantu akan dilakukan setelah pengamatan ke-2 dilakukan dan diskusi antara tim mitra dan tim penulis selesai dilakukan. Diharapkan bahwa hasil dari PKM ini dapat bermanfaat tidak hanya kepada responden dari mitra tapi juga dapat dijadikan acuan untuk masyarakat umum dengan diagnosa dan prognosis yang serupa untuk menunjang pendidikan disabilitas lebih maksimal.

\section{Ucapan Terima Kasih (Acknowledgement)}

Kami berterima kasih kepada Lembaga Penelitian dan Pengabdian kepada Masyarakat (LPPM) Universitas Tarumanagara atas terselenggaranya program Pengabdian kepada Masyarakat di Yayasan Sayap Ibu cabang Bintaro, Banten. Bantuan nyata dalam kerja sama yang bersinergi dari Yayasan Sayap Ibu cabang Banten juga merupakan sebuah dukungan yang sangat kami hargai, untuk itu kami ucapkan banyak terima kasih terutama kepada Bapak Agus Triharyanto S.Pd Khusus selaku kepala sekolah Yayasan Sayap Ibu cabang Banten dan semua tim terapis, guru, hingga pengasuh dari YSI yang sangat antusias serta tanpa pamrih membantu kami merealisasikan kegiatan ini secara nyata.

\section{REFERENSI}

Adelman, H.S. , \& Taylor, L. (1985). The future of the LD field. Journal of Learning Disabilities, 18, $422-427$.

Galal, G.H. and McDonnel, J.T. "Knowledge-Based Systems in Context: A Methodological Approach to the Qualitative Issues,” AI \& Society (11), 1997, pp. 104-121.

Hughes, J. and D, H. "Grounded Theory: Never Knowingly Understood," Information Systems Review (1), 2000, pp. 181-197.

Orlikowski, W. "CASE tools are organizational change: Investigating Incremental and Radical Changes in Systems Development," MIS Quarterly, (17:3), 1993, pp. 309-340.

Palisano R, Rosenbaum P, Walter S, Russell D, Wood E, Galuppi B. Development and reliability of a system to classify gross motor function in children with cerebral palsy. Dev Med Child Neurol. 1997;39(4):214-23.

Shamsoddini A, Amirsalari S, Hollisaz MT, Rahimnia A, Khatibi-Aghda A. Management of spasticity in children with cerebral palsy. Iran J Pediatr. 2014;24(4):345-51

Somantri, Sutjihati. (2005). Psikologi Anak Luar Biasa. Bandung: PT Refika Aditama

Sumaatmadja, Nursid. 2002. Pendidikan Pemanusiaan Manusia Manusiawi. Bandung: Alfabeta. 2002: 49

Novak I, Morgan C, Adde L, Blackman J, Boyd RN, Brunstrom-Hernandez J, et al. Early, accurate diagnosis and early intervention in cerebral palsy: Advances in diagnosis and treatment. JAMA Pediatr. 2017;171(9):897-907 